Valóságos könyvtár - könyvtári valóság. Könyvtár- és információtudományi tanulmányok 2016. Szerk. Kiszl Péter, Boda Gáborné Köntös Nelli. Budapest, ELTE BTK Könyvtár- és Információtudományi Intézet. 2017. 169-176.

\title{
A HALLGATÓK PERCEPCIÓJA A KÖNYVTÁROS HIVATÁSRÓL
}

\author{
SENKEI-KIS ZOLTÁN \\ ELTE BTK KITI, egyetemi adjunktus
}

\begin{abstract}
ABSZTRAKT
A könyvtáros szakma jövője szempontjából nagyon fontos, hogyan vélekednek a jövő könyvtárosai, azaz az informatikus könyvtáros hallgatók a választott pályájukról. A későbbi sikeres szakmai pályafutás szempontjából fontos, hogy egyetemi éveik alatt hogyan viszonyulnak a hivatáshoz, hogyan alakul szakmai szocializációjuk. Ezért tartottam fontosnak, hogy a hallgatók percepcióját elemezzem. Kutatásomban arra kerestem választ, hogy milyen ma Magyarországon a könyvtáros hivatás megítélése, hol a szakma helye a 21. században. Vizsgálatomban informatikus könyvtáros alap- és mesterképzésú hallgatók vettek részt. Négy fókuszcsoportos interjút készítettem. A fókuszcsoportos interjú módszere alkalmas arra, hogy egy szakmai közösség tagjainak reprezentációit összefüggéseiben tárjuk fel. Az interjúk anyagát tartalomelemzéssel dolgoztam fel. Főbb tartalmi körök az alábbiak: pályaválasztási motiváció, a szakma külső és belső megítélése, társadalmi hasznosság, képzés hozzáadott értéke, képzés eredményessége, a diploma értéke, szakmai identitás, jövőkép.
\end{abstract}

Érdekes, hasznos és tanulságos egy-egy szakma vizsgálata a képzés tekintetében, hiszen a legfontosabb észrevételeket azok az emberek tudják adni, akik hallgatókként részesei ennek. Egy ilyen kutatás segít összhangot teremteni hallgatók és oktatók, követelmények és elvárások között, visszajelzést kapunk a szakmáról, a képzésről. Az Eötvös Loránd Tudományegyetem Bölcsészettudományi Karán működő Könyvtár- és Információtudományi Intézet, mint a hazai könyvtárosképzés fellegvára, nagy hangsúlyt helyez a képzés folyamatos fejlesztésére, ezért rendszeresen szondázza hallgatóit annak érdekében, hogy a diploma kézhezvételekor elégedetten, a hivatás szeretetével, jó szakemberként kezdjék meg könyvtáros pályafutásukat.

Bevezetés

Az emberek vélekedéseivel, a hétköznapi diskurzusok során kialakított világképpel a szociális reprezentáció elmélete foglalkozik. A szociális reprezentációk a kommunikáció, vagyis a személyközi interakciók során jönnek létre. ${ }^{1}$ Moscovici szerint ${ }^{2}$ az interperszonális folyamatokban kialakuló társadalmi viszonyoktól haladva jutunk el az egyénig, tehát az egyén vizsgálatában fontos szerepet játszanak a kulturális, társadalmi, társas tényezők is. A reprezentációk meghatározzák, alakítják az egyén, illetve a közösség, cselekvését és véleményformálását azzal, hogy összekötik a már meglévő tudást az isme- 


\section{SENKEI-KIS ZOLTÁN}

retlen jelenségek között. A szociális reprezentációk a társadalmi és egyéni megismerés közötti kölcsönhatás termékeiként jellemezhetők. ${ }^{3}$

Abric ${ }^{4}$ írta le a szociális reprezentációk általános struktúráját. A reprezentációkat központi és perifériás részekre osztotta. A reprezentáció központi magját a reprezentáció fő jelentését adó néhány elem alkotja, a mag határozza meg alapvetően a reprezentáció jelentését. Mivel ezekben a központi magot alkotó elemekben nagy a konszenzus, a központi mag stabil, a reprezentációnak ez a része áll ellen legjobban a változásoknak. A periféria elemei a mag köré szerveződnek, árnyalják a mag jelentését, a valósághoz igazítják a reprezentációt. A periférikus elemek konkrétabbak, a környezettel szorosabb kapcsolatban lévők, kevésbé állnak ellen a változásnak. ${ }^{5}$

A szociális reprezentációk vizsgálata lehetővé teszi, hogy feltárjuk az adott csoport gondolkodásmódját, amely az egymással folytatott kommunikáció eredményeképp jön létre. A szociális reprezentációk vizsgálata azt is lehetôvé teszi, hogy feltárjuk azt a sajátos jelentésadási módot, ahogy a csoport értelemmel ruházza fel a valóságot. ${ }^{6}$

A formális logika szabályai kevésbé érhetők tetten a reprezentációk struktúráiban, mivel a hétköznapi emberek hétköznapi konszenzusos tudását tükrözik. ${ }^{7}$ A reprezentációk fogalmakkal, fogalomcsoportokkal írhatók le, amelyek hálózatosan kapcsolódnak egymáshoz.

\section{A kutatás célja, módszerei}

A kutatás célja az informatikus könyvtáros hallgatók vélekedéseinek feltárása választott pályájukról. Arról szerettem volna képet alkotni, hogyan viszonyulnak a könyvtáros hivatáshoz az egyetemi évek alatt, hogyan alakul szakmai szocializációjuk a vélekedéseik tükrében, milyen ma Magyarországon a könyvtáros hivatás megítélése, valamint hol a szakma helye a 21. században.

A hallgatói vélekedések feltárásához fókuszcsoportos interjúkat készítettem. A módszer kiválóan alkalmas egy adott közösség által létrehozott reprezentációk feltárására, a diskurzusok során feltáruló képek mélyebb rétegeinek az elemzésére. Négy interjút vettem fel, két BA csoporttal (10 és 11 fö), illetve két MA csoporttal (8 és 9 fö). Az adatfelvétel a 2015 tavaszi és őszi félévében történt. Az adatokat a szociális reprezentáció elméleti keretében dolgoztam fel, valamint a fő tartalmi köröket tartalomelemzéssel vizsgáltam meg. A főbb tartalmi körök a következők voltak: pályaválasztási motiváció, a szakma külső és belső megítélése, a képzés hozzáadott értéke, a diploma értéke, szakmai identitás, jövőkép.

\section{Pályaválas z̧tási motiváció}

Az első tartalmi kör a pályaválasztási motiváció kérdésére irányuló tartalmakat foglalja magában. A pályaválasztás miértje fontos szerepet tölt be a fiatalok későbbi, szakmáról alkotott képében. Vegyes a kép, hiszen többen tudatosan választották ezt a pályát, de vannak, akik ,véletlenül” kerültek a könyvtár szakra. A válaszadók többsége a pályaválasztást valamilyen pozitív könyvtári élményre vezeti vissza, ebben kiemelkedő a könyvtáros mint példakép, valamint a könyvtárak jó hangulatának szerepe (1. ábra). 
A HALLGATÓK PERCEPCIÓJA A KÖNYVTÁROS HIVATÁSRÓL

„Gimnáziumban sokat jártam könyvtárba, és a könyvtáros véleményét kikértem negyedikben, hogy hová menjek. Ö ąt mondta, hogy jó könyvtáros lennék." (BA hallgató)

„Az iskolai könyvtáros munkáját látva döntöttem a szak mellett.” (MA hallgató)

„Szeretem a könyvtárak hangulatát." (MA hallgató)

Vannak olyan hallgatók, akik a szakról összegyüjtött információk alapján döntöttek e képzés mellett. Az informatika, információtudomány és adatbázisok bizonyultak különösen vonzónak.

"Az informatika szó megfogott." (BA hallgató)

„A választható sqakirányok miatt jöttem ide." (MA hallgató)

„Információkeresés, adatbázisok vonzottak ide.” (BA hallgató)

Többen más szak, főként magyar szak után jelentkeztek.

„Magyar szake után szerettem volna gyakorlatiasabb dologgal foglalkozni." (MA hallgató)

„Magyar szak után választottam a könyvtár szakot, mert közelállónak gondoltam.” (BA hallgató) „Informatikus voltam, ez jól kiegészíti ąt.” (MA hallgató)

Természetesen a könyvtár szakos hallgatók között is vannak olyanok, akiknek még nincs kiforrott jövőképük, vagy a diplomaszerzés lehetséges eszközének tartják a könyvtár szakot.

„Ide vettele fel.” (BA ballgató)

„Nem volt elképzelésem, ez volt a legszimpatikusabb szak.” (BA hallgató)

Magyar szak melletti szak

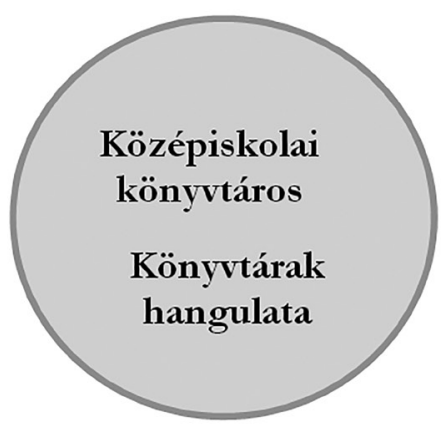

Információkeresés, adatbázisok

Diplomaszerzés

1. ábra: Pályaválasz̧ási motiváció

A sqakma külsö és belsö megitélése

A hallgatók szakmai szocializációját alapvetően meghatározza a szakma társadalmi megítélése, a hallgatók szakmáról alkotott képe, ezért a vizsgálatban kitértem a szakmai 


\section{SENKEI-KIS ZOLTÁN}

külső - nem szakmabeliek általi - megitélésére, de foglalkoztam a hallgatóknak a könyvtárosi hivatásról alkotott reprezentációjával is.

A könyvtáros szakma külső megítélése a hallgatói vélekedések alapján inkább negatívnak mondható. A hallgatók szerint a közvélemény még mindig sztereotípiákban látja a könyvtárost és a könyvtárosi munkát. A sztereotípia egyrészt az olvasásra, mint a könyvtáros fő tevékenységére épül, másrészt a tipikus könyvtáros személyiséget foglalja magában, többen is kiemelik, hogy a könyvtárosok segítőkészek, olvasottak, zárkózottak (2. ábra).

„A könyvtárosnak nem kell mást tudni, csak az abc-t.” (BA hallgató)

„A könyvtáros nem csinál semmit, egész nap ül és olvas.” (MA hallgató)

Az is többször elhangzott az interjúkban, hogy az átlagemberek nem csak azt nem tudják, hogy miből áll a könyvtáros munkája, de a képzésről sincs sok információjuk.

„Nem értékeli a társadalom túl nagyra, mert nem is tudják, hogy mit csinál egy könyvtáros.” (BA ballgató)

„Nem is tudjáke, hogy ez̨t egyetemen oktatják..” (MA ballgató)

„Láthatatlan a munkája, háttérmunka.” (MA hallgató)

Nagyon markánsan jelent meg a reprezentációkban a szakma alacsony anyagi megbecsültsége, amely sokat ront a külső megítélésen, csökkenti a szakma presztízsét.

„Nem becsülike meg, hiába dolgozile többet, alacsony a bér.” (BA hallgató)

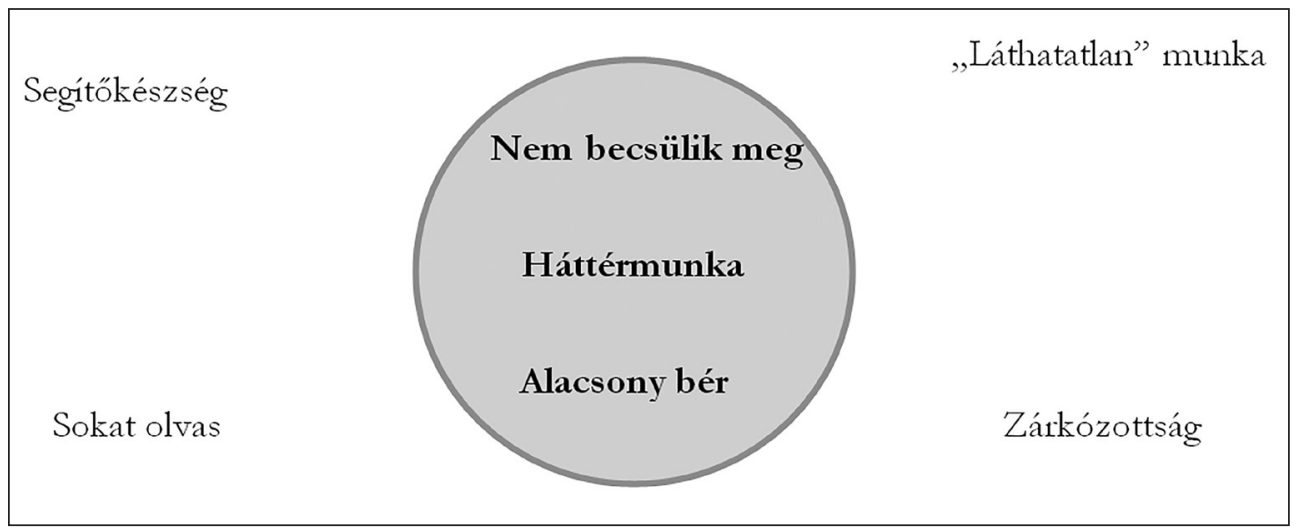

2. ábra: A szakma külsö megitélése

A hallgatók személyes véleménye a szakmáról, annak hasznáról nagyban eltér a külső megítéléstől, jóval pozitívabbnak mondható, de természetesen itt is megjelennek a negatívumok. A hallgatók vélekedése ebben az esetben sokkal differenciáltabb a szakmáról, mint a külső megítélés esetében, ami valószínúleg annak köszönhető, hogy a szakmai szocializáció, a tanulmányok és szakmai gyakorlatok során szerzett tapasz- 
talatok hatására nagyobb bepillantást nyernek a hivatásba. Többen emelik ki a könyvtárosi munka hasznosságát, mely leginkább a szellemi termékek létrehozásában mutatkozik meg (3. ábra).

„Az információs társadalomban nagy értéke van az információnak, ezért az adatbázisokban jártas könyvtárosok társadalmi haszna nagy." (BA hallgató)

„Sok mindent elérhetövé tesžnek, tehát nagyon hasżnos a munkájuk." (MA hallgató)

A hallgatók reprezentációiban már megjelennek a könyvtáros szakma újabb feladatai és szerepei, pl. sokan kiemelik a könyvtárak és könyvtárosok szociális funkcióit.

„V an hasఇna, sqórakoztatást biztosit, társas térként is funkcionál.” (BA hallgató)

„Hasznos az emberi kapcsolatokban, beszélgetni lehet, föleg kis könyvtárakban, emberi szót hallhatunk. Lehet internetezni, állást keresni. Nevelési feladatokat is ellát.” (MA hallgató)

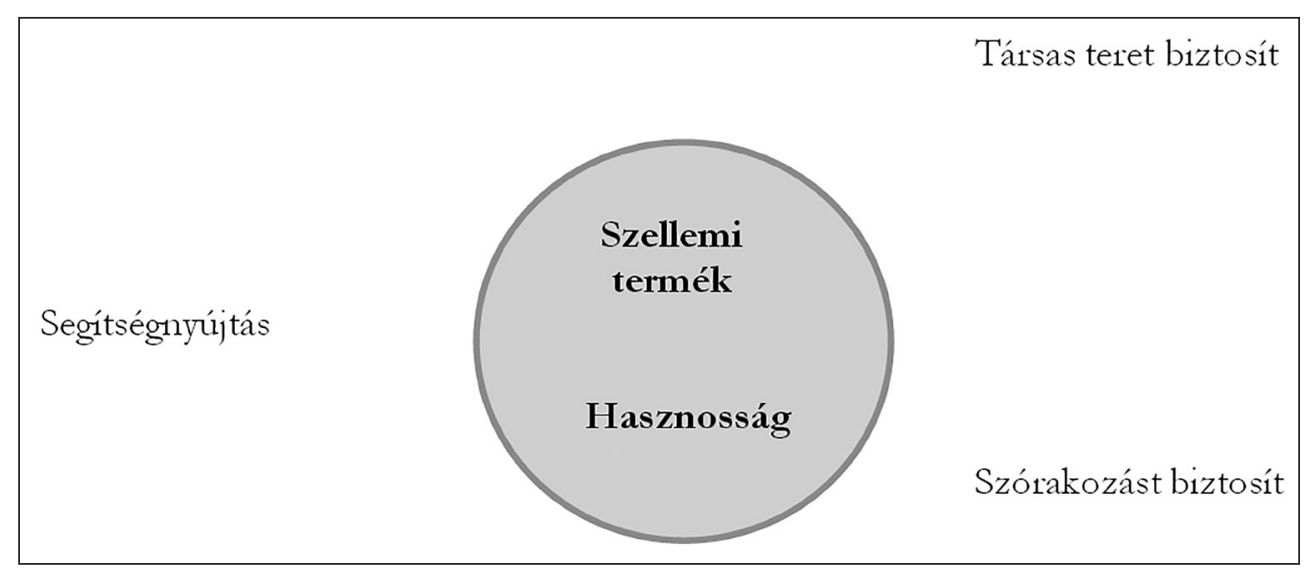

3. ábra: A szakma belsö megitélése

\section{A képzés hozzáadott értéke}

A képzés hozzáadott értéke tartalmi kör az ELTE Könyvtár- és Információtudományi Intézet alap- és mesterszakos képzései által nyújtott értékekre fókuszált. Örömteli, hogy a hallgatók több olyan kompetenciát is meg tudtak nevezni a pozitívumok között, melyek megfelelnek az Európai Unió által megfogalmazott kulcskompetenciáknak. A kompetenciák közül legtöbben az információkeresési képességek fejlődését emelték ki, de sokan említették a kommunikációs készségek, társas készségek fejlődését is. Szintén a szakmai szerep gazdagságát tükrözi a szükséges kompetenciák sokfélesége: a digitálistól a kulturálisig (4. ábra).

„(A képzés) fejleszti az információkeresési készséget.” (BA hallgató)

„Fejlesz̨ti az elöadói készséget a sok elöadás, amit tartani kell.” (MA hallgató)

„Kulturális kompetenciát fejlesðฺt, mivel sokeféle dolgot kell tanulni, tágítja a világképet.”(B A ballgató) 


\section{SENKEI-KIS ZOLTÁN}

„Anyanyelvi kompetencia, szociális kompetencia: olvasók.kal, kollégákkal a kapcsolat.” (BA hallgató) „Digitális kompetencia, pl.: adatbázisok használata.” (BA hallgató)

„Idegen nyelvi kompetencia, pl.: angol szaknyelv, idegen nyelvü adatbázisok hasżnálata.” (MA ballgató) „Lényegkiemelés képessége fejlödik." (MA hallgató)

„Kapcsolatteremtésben fejlödtem.” (MA hallgató)

Sok képzésnek sarkalatos pontja a szakmai gyakorlat, több szak esetében a hallgatók keveslik a gyakorlatok számát. A hallgatói vélekedések alapján az mondható, hogy többségében elégedettek a hallgatók a szakmai gyakorlatokkal, a képzés erényei között említik.

„Jó, hogy sok szakmai gyakorlat van, és ezeken megmutatják a szakma lényegét." (MA hallgató)

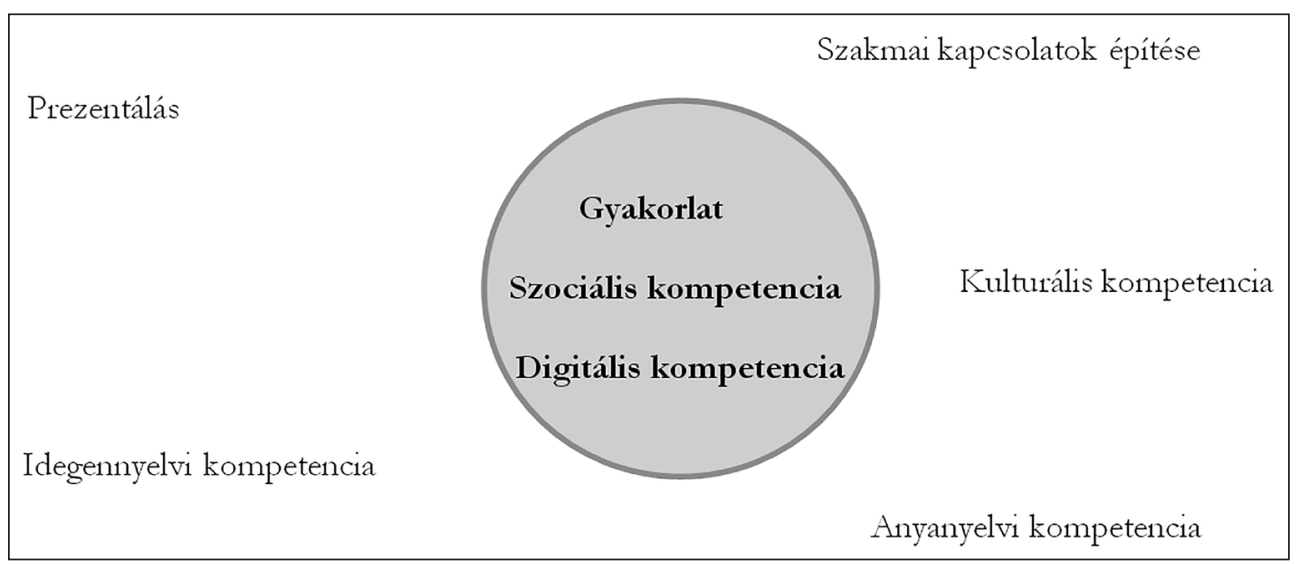

4. ábra: A képzés bozzáadott értéke

\section{A ballgatók jövóképe}

Az utolsó tartalmi kör a jövőképet írta le. A szakmai szocializáció szempontjából kiemelten fontos, hogy a leendő könyvtárosok milyen elvárásokkal, attitűdökkel kezdik el a munkát, hiszen ezek nagyban meghatározzák a későbbi szakmai fejlődésüket. Másrészt a tanszék szempontjából is fontos, hogy a hallgatóik mennyire pozitív jövôképpel rendelkeznek, mennyire motiváltak, a szakmában kívánnak-e elhelyezkedni, vagy esetleg pályaszocializációs problémákkal küzdenek.

A hallgatók arra a kérdésre, hogyan látják magukat, milyen munkát fognak végezni a jövőben (tíz év múlva), döntő többségben a könyvtáros hivatás gyakorlását említették: gyermekkönyvtárban, szakkönyvtárakban szeretnének elhelyezkedni (5. ábra).

„Szakkönyvtáros leszek egy országos sqakkönyvtárban.” (BA hallgató)

„Feldolgozó könyvtáros leszele egy városi könyvtárban.” (MA hallgató) „Meghúzódni egy sarokban, békében egy könyvtárban.” (BA hallgató) 
A HALLGATÓK PERCEPCIÓJA A KÖNYVTÁROS HIVATÁSRÓL

„Könyvtárban dolgoznék, vagy komplex kulturális intézményben, ahol rendezvények is vannak." ( $M$ A hallgató)

„Gyerekeönyvtárban fogok dolgozni.” (BA ballgató)

A hallgatói tervek között néhány esetben megjelenik a könyves szakma, valamint a képzéshez köthető információtudomány néhány területe.

„Föszuerkesztô leszek egy könyvkiadónál.” (MA ballgató)

„Könyvhör. kapcsolódó munkahelyen szeretnék dolgozni.” (BA hallgató)

„Információbróker szeretnék lenni.” (MA hallgató)

„Marketinges munkát képzelek el magamnak.”" (MA hallgató).

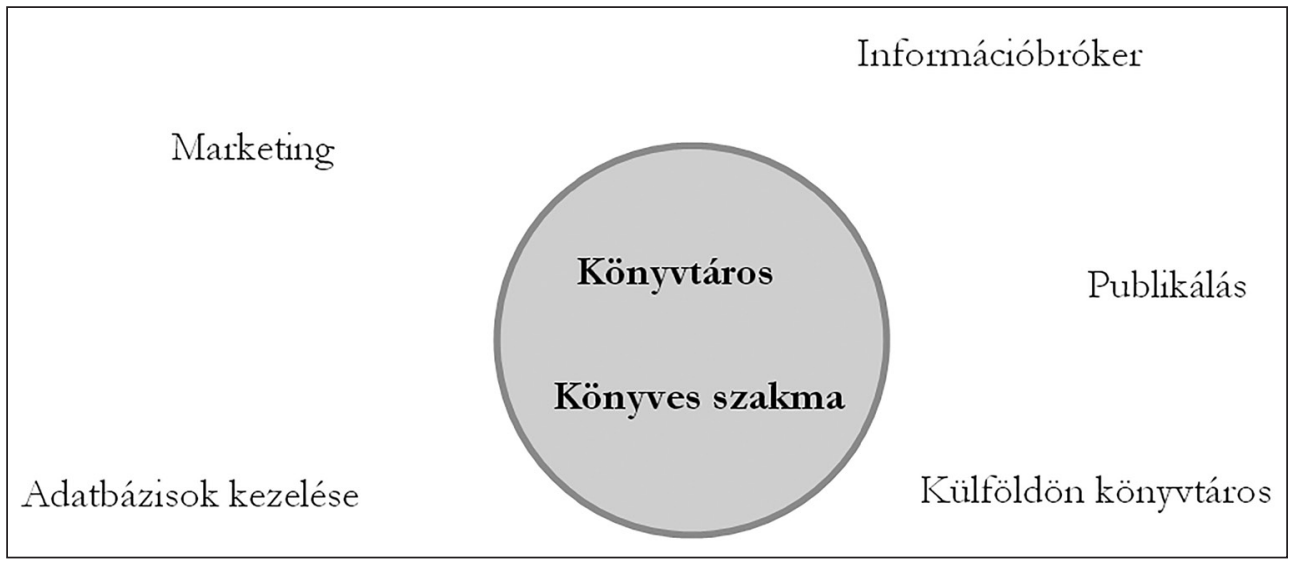

5. ábra: A hallgatók jövöképe

\section{Összegzés}

A hallgatói vélekedések vizsgálatával feltárhatjuk a szakmáról alkotott kép struktúráját, tisztázhatjuk a hallgatók attitűdjeit, elvárásait a pályával kapcsolatban. A hallgatói vélekedések elemzésével elősegíthetjük a hallgatók szakmai szocializációját, felhívhatjuk a figyelmet a pályaszocializációs problémákra.

A kutatási eredmények azt mutatják, hogy a hallgatók percepcióiban határozottan szétválik a külső és belső szakmai kép, vagyis a hallgatók máshogy vélekednek a könyvtárosi hivatásról, mint ahogy szerintük a nem szakmabeliek vélekednek. Természetes, hogy egy adott szakma múvelői differenciáltabban, kevésbé sztereotipikusan, több pozitív tartalommal jellemzik a hivatásukat, mint a kívülállók. Azonban ha az adott szakma külső megítélése egyöntetűen negatív, élesen elválik a szakmáról alkotott külső és belsô kép, akkor az későbbi pályaszocializációs problémához, elakadáshoz vagy akár pályaelhagyáshoz is vezethet. Ezért fontos még a képzés során a hallgatók pályaszocializációját fókuszba helyezni, hogy kiforrott szakmai identitással lépjenek ki a munka világába. 
SENKEI-KIS ZOLTÁN

\section{Irodalom és jegyzetek}

${ }^{1}$ KISS Paszkál: Szociális reprezentáció, ahogy a közösség megszelídíti az ismeretlent. = Pedagógusképzés, 7. (36.) évf. 2-3. sz. 2009. 89. p.

${ }^{2}$ MOSCOVICI, Serge: Társadalom-lélektan. Budapest, Osiris Kiadó, 2002. 417 p.

${ }^{3}$ KISS Paszkál: i. m.

${ }^{4}$ ABRIC, J. C.: Les représentations sociales: aspects théoriques. In: Pratiques sociales et représentations. ed. J. C. Abdric, Paris, PUF, 1994. 10-36. p.

${ }^{5}$ KISS Paszkál: i. m.

${ }^{6}$ KISS Paszkál: i. m.

${ }^{7}$ MOSCOVICI, Serge: i. m.

Senkei-Kis Zoltán az ELTE BTK Könyvtár- és Információtudományi Intézetének oktatója, az informatikus könyvtáros szakmai gyakorlatok felelőse. Az ELTE BTK Esélyegyenlőségi Bizottságának elnöke. Kutatási területe: irodalomterápia, hallgatói kompetenciák. 